Vol. LXVI 2015

\title{
ASPECTS CONCERNING THE RULES AND THE INVESTIGATION OF TRAFFIC ACCIDENTS AS WORK ACCIDENTS
}

\author{
TARNU Lucian Ioan \\ Faculty of Engineering/Department IIM “Lucian Blaga” University, of Sibiu, Romania, \\ lucian_tarnu@yahoo.com
}

\begin{abstract}
When Romania joined the European Union, it was imposed that the Romanian legislation in the field of the security and health at work be in line with the European one. The concept of health as it is defined by the International Body of Health, refers to a good physical, mental and social condition. The improvement of the activity of preventing the traffic accidents as work accidents must have as basis the correct and accurate evaluation of risks of getting injured. The goal of the activity of prevention and protection is to ensure the best working conditions, the prevention of accidents and occupational diseases and the adjustment to the scientific and technological progress. In the road transport sector, as in any other sector, it is very important to pay attention to working conditions to ensure a workforce motivated and well qualified.Some features make it a more difficult sector risk management than other sectors. However, if one takes into account how it works in practice this sector and the characteristics of drivers and how they work routinely, risks, dangers and threats can be managed efficiently and with great success.
\end{abstract}

\section{Introduction}

Within the European Union, promoting health and safety at work is a joint effort made by employers, employees and society to improve health and wellbeing at work. at work.

Promoting the health of employees at work is more than legal requirements of health and safety

Traffic accident with serious consequences is a painful event, and if time can not be given back ever, yet its consequences and effects can be reduced. Firstly, it is part of the prevention and then representing insurance.

Of all workplace accidents, a rate of about $17 \%$ occur in traffic, and about a quarter of the victims of accidents at work and found the end as a result of a traffic accident. Strictly, they have the particularity to be treated as work accidents, which brings certain facilities on health care and insurance, reducing at some extent the suffering of those involved directly or indirectly.

\section{Traffic accidents}

According to the provisions of the Romanian legislation ${ }^{1}$, there are two categories of work accidents that take place as consequence of the traffic on public routes.

The first of preferring traffic accident at work is defined as accident arising out of traffic on public roads or road traffic, whether the injured person was in fulfillment of duties.

There are also so-called traffic accidents, which may be the accident that occured during the regular route from work to home and back, and which generated the injury or death, the accident occured during lunch breaks taking places on the premises arranged by the employer on the regular route from work to the place where he has lunch break and back and which generated the injury or death and, respectively, the accident which generated the injury or death that occured on the regular way from work and the place where he gets the salary and back, if the latter one is outside the institution ${ }^{2}$.

It was quantified that a fatal traffic accident in Romania costs about half a million euros. This figure is given by the fact that among the consequences of the accident, there is a number of direct and indirect costs.

The direct costs include all costs related to temporary disability benefits, first aid costs (transport, taking care), the costs of repairing (glasses, hearing aid, etc.), medical rehabilitation (surgery, medication,

\footnotetext{
1 Occupational health and safety law no. 319/2006 and Government Decision no.1425/2006 approving the Methodological Rules for the application of Law no. safety and health. 319/2006 as amended and supplemented. This law is the transposition of European Directive 89/391 / EEC.

2 art. 2 point 10 of the Implementing Rules of the Law no. 319/2006 approved through the Government Decision no. $1425 / 2006$.
} 
antiseptic environment, staying in hospital, final medical control, etc), professional rehabilitation (training, courses,etc.), professional recovery (treatments, prosthesis, rehabilitation at work place), or compensations (death, social case, pensions, etc.).

The indirect costs are those which are often difficult to be assessed at the true dimensions.

The indirect costs are supported by the employer and difficult to be strictly assessed. For this reason, many people ignore them, mainly, for the disdain for the qualified work force.

\begin{tabular}{|c|c|}
\hline \multicolumn{2}{|l|}{ INDIRECT COSTS } \\
\hline 1. Salary costs & $\begin{array}{l}\text { - payment of sick leave on the first day; } \\
\text { - social support; } \\
\text { - payment of the time necessarily spent for } \\
\text { the accident investigations; } \\
\text { - payment of the time that the employees } \\
\text { spent in investigation as witnesses; } \\
\text { - time spent with the hiring of another } \\
\text { person; } \\
\text { - time necassary to train the new employed } \\
\text { person; }\end{array}$ \\
\hline 2. Material costs & $\begin{array}{l}\text { - value of the wasted materials; } \\
\text { - value of damaged technical equipments; } \\
\text { - cost of the repairing of technical } \\
\text { equipements. }\end{array}$ \\
\hline 3. Service/job costs & $\begin{array}{l}\text { - the appeal to the third parties, when it is } \\
\text { imposed. }\end{array}$ \\
\hline $\begin{array}{l}\text { 4.Costs due to the interruption of } \\
\text { production from the moment of accident to the } \\
\text { beginning of activity }\end{array}$ & \\
\hline 5. Other costs & $\begin{array}{l}\text { - penalties for late delivery; } \\
\text { - damage of the company image among its } \\
\text { clients; } \\
\text { - overassessment of products; } \\
\text { - penalties; } \\
\text {-fines for the accident. }\end{array}$ \\
\hline \multicolumn{2}{|c|}{ COSTS THAT CAN NOT BE CALCULATED } \\
\hline $\begin{array}{l}\text { Supported by the victim. These costs refer } \\
\text { to the financial loss in the budget of the due family }\end{array}$ & $\begin{array}{l}\text { - reducing of real earning; } \\
\text { - additional expenses related } \\
\text { hospitalization; } \\
\text { - disruption of family life, the suspension } \\
\text { of works; } \\
\text { - giving up some projects; } \\
\text { - climate change in marital and social } \\
\text { environment due to irritability of victim; } \\
\text { - victim's behavior changes towards work } \\
\text { and colleagues ; } \\
\text { - difficulties or impossibilities to continue } \\
\text { working. }\end{array}$ \\
\hline
\end{tabular}

Direct costs refer in particular to the victim and employment varies by accident or whether it is considered to be working ones. Many of these costs are reimbursed by the National Health Institution only if really falling in the category of work accidents.

Theoretically, all persons insured within the health insurance system in Romania and all employers who are registered in Romania should have the obligation to pay contributions to the National Health and Social Insurance Fund. 
According to Government Decision no.355/2007 regarding employees' health surveillance ${ }^{3}$, „At work framing, as well as on the occasion of periodic medical workers who compete at traffic safety in railway transport sector, aviation, naval and of drivers, as well as other categories of workers carrying out specific activities, and examinations shall be carried out by special regulations, in order to go if the health conditions allow them to complete the work which they are entrusted".

In this regard, firms/road transport companies as employers, were indeed those two obligations referred to above, namely the obligation to pay contributions to the Social Security Health Insurance Fund and the obligation to carry out the medical examinations and mandatory psychological staff that contributes to the security and safety of road traffic. What is strange, however, is the fact that the two obligations are governed by different regulations which are not complementary.

Medical and psychological examinations required for the personnel involved in safety, as set out in Order no. 447/2003 approving instructions for medical examination and psychological personnel with responsibilities in transport safety and navigation, are part of the preventive medical services group for the health surveillance of workers and shall only be subject to the provisions of law no. 319/2006 concerning safety and health in the workplace as amended and supplemented, and Government Decision no. 355/2007.

The national health insurance card is the document which proves that the holder thereof is provided in the system of health insurance in Romania. In turn, the European document entitling the holder is guaranteed the right to necessary medical assistance during a temporary stay in a Member State of the European Union.

It should be mandatory for any driver who runs through the rest of Europe.

Basically,when there is mutual consideration both in state - employers relationship and employers - drivers, then, there are fewer car accidents and their consequences are lower.

\section{The question we must answer is the following: when the traffic accident can be considered as accident at work?}

The traffic accident recorded as accident at work is for the benefit of the employee because it makes it possible the payment of sick leave for temporary incapacity for work during the period in which the employee is unable to work. However, in order to be considered as accident at work, the traffic accident must meet several conditions.

Law on safety and health at work no. 319/2006 lays down in article 5, letter g) - the accident as the violent body injury, and acute professional intoxication, taking place during employment or in carrying out their duties and causing temporary incapacity ${ }^{4}$ or at least three calendar consecutive days, invalidity $^{5}$ or death ${ }^{6}$. Methodological rules for the application of law no.319/2006, approved by Government Decision no. 1425/11.10.2006, defined in article 2, point 5, the accident that produces temporary incapacity at work of at least 3 consecutive calendar days confirmed by medical certificate or, where appropriate, through other documents according to legal provisions.

The law on health and safety at work lays down the obligation of the employer to keep track of accidents at work that have the incapacity for work for more than three days of work, the light of the accidents occupational diseases, dangerous incidents and accidents at work, as defined clearly in the article 5, letter g).

\section{How the traffic accident is defined}

The article 30, paragraph 1 of the law, states that for the purposes of the provisions of article 5 , letter g), the work accident is also the traffic accident, if the movement was done during the regular from the employee's residence to work organized by the employer and back.

It is also very important that the movement to be made without undue deviation from the regular route and transport to be made under the regulations for safety and health at work or service in force.

The laws and regulations concerning the traffic accidents are for the benefit of employees, since a traffic accident recorded as accident at work makes possible the payment of sick leave for temporary

\footnotetext{
${ }^{3}$ Government Decision no. 355/2007 was published in the Official Journal of Romania no. 332/17.05.2007.

${ }^{4}$ Temporary incapacity is the least serious consequence of an accident at work and consists of temporary inability of the victim to engage in activity as a result of a functional disorder for at least 3 calendar days.

${ }^{5}$ Disability is a permanent disablement, which lead to total or partial loss of capacity for work, and loss of a sense, organ, cranial, thoracic, abdominal traumas, etc.

${ }^{6}$ Death is the most severe consequence of an accident at work, and a work accident can be considered mortal, even if death occurred after a period of time, provided that it is confirmed by a medical evidence that it has occurred as a consequence of an accident at work.
} 
incapacity in the amount prescribed by the Law no. 346/2002 as amended and supplemented ${ }^{7}$, on insurance against accidents at work and occupational diseases.

For if the accident resulted in the death of the victim or compliance with a degree of disability of the victim, shall also apply to the provisions of the collective labour contract at the unit/branch level, i.e. public pensions Act (if applicable-death grants for the offspring of the Retirement Institution, material and financial support from the employer for the victim survivors, etc.).

Legislative provisions are for the benefit of the employer, if it's mentioned in the schedule of individual training on safety and health at work:

- employees's way work to ho home and back;

- $\quad$ the total period of time needed for movement (specify mandatory the schedule and the hours total time that is necessary from home to work and back).

In case the employer filled in this training data sheet, he may not be fined or held responsible for administrative offences in criminal law for the production of the event.

In the individual training sheet on safety and health at work, the route and duration is stated by the person carrying out the general introductory training, at the beginning of the process of filling in the sheet, where you write the employee's personal information.

The employee's signature on the individual training sheet on safety and health at work certifies that it has been appropriately trained by the employer.

It must be known that, if the employer provides the employee's transportation from home to work and back, by his own means of transport or by rented vehicles, this will be mentioned in the individual training sheet on safety and health at work showing the route to be followed and the time period required to move from home to work, and from work to home.

In addition, the provisions of the individual training sheet on safety and health at work of employees on the way to be followed and the periods of time required to transport employees will be referred to in the provision of services concluded by the employer with the firm that rents the means of transport because the transport company must be aware of these provisions and to observe them. Not respecting these provisions, the company of transport carries strictly this responsibility.

Considering the traffic accidents to or from the place of dining or getting the salary, the employer must draw up and approve a written document in which to establish the regular route of movement of employees from the workplace where it serves the lunch and back, and the time period when the movement takes place, i.e. the regular route of movement from the workplace where employees collect their salary and back as well as the time period when the movement takes place. These provisions can be found in the rules of procedure, which shall be brought to the attention of all employees in that institution.

Employers are required, by the Law of health and safety at work, to inform the authorities of any event that occurs within the institution, whether it comes to occupational diseases, accidents at work and route accidents.

According to the article 5, letter f) of the Law on safety and health at work no. 319/2006, an event is defined as: the accident that has entailed the death or injury of the body during the process of work in carrying out their duties, every person whose whereabouts situation or traffic accident or movement, as provided by the persons employed were involved, the dangerous incident, and cases of occupational disease or are likely related to the profession.

The categories of information that shall be submitted to the Territorial Labor Inspectorate and the insurance company.

As mentioned, the employer has the obligation to communicate all events as defined in the article 5 letter f) of the Law no. 319/2006 addressed to the Territorial Labor Inspectorates.

Furthermore, methodological rules for the application of the Law no. 319/2006, approved by the Government Decision no. 1425/2006, establish that shall be communicated as obligatory the following: a dangerous incident, the event which resulted in a death, the event that resulted in a collective crash, the event which resulted in a crash followed by an obvious disability, the event which resulted in a crash followed by invalidity, the event which resulted in the disappearance of a people.

In the latter two cases, the events shall be notified to the labor inspection on the receipt of the decision of employment in a degree of disability.

According to the article 50 of Law no. 346/2002 on insurance for accidents at work and occupational diseases, the employer must inform the insurance company regarding the accidents

\footnotetext{
7 Law no. 346/2002 as amended and supplemented, on insurance against accidents at work and occupational diseases was published in the Official Journal of Romania no. 772/12.11.2002.
} 
resulting in incapacity for work or death of the insured, as well as hazardous incidents as soon as employers were aware of their production.

In the case of traffic accidents produced on the road, resulting in the death of victims in which some are victims and persons in the performance of duties of road services shall notify the Territorial Labor Inspectorate in the county within which the accident occurred.

Also the information specified above shall be notified to the police.

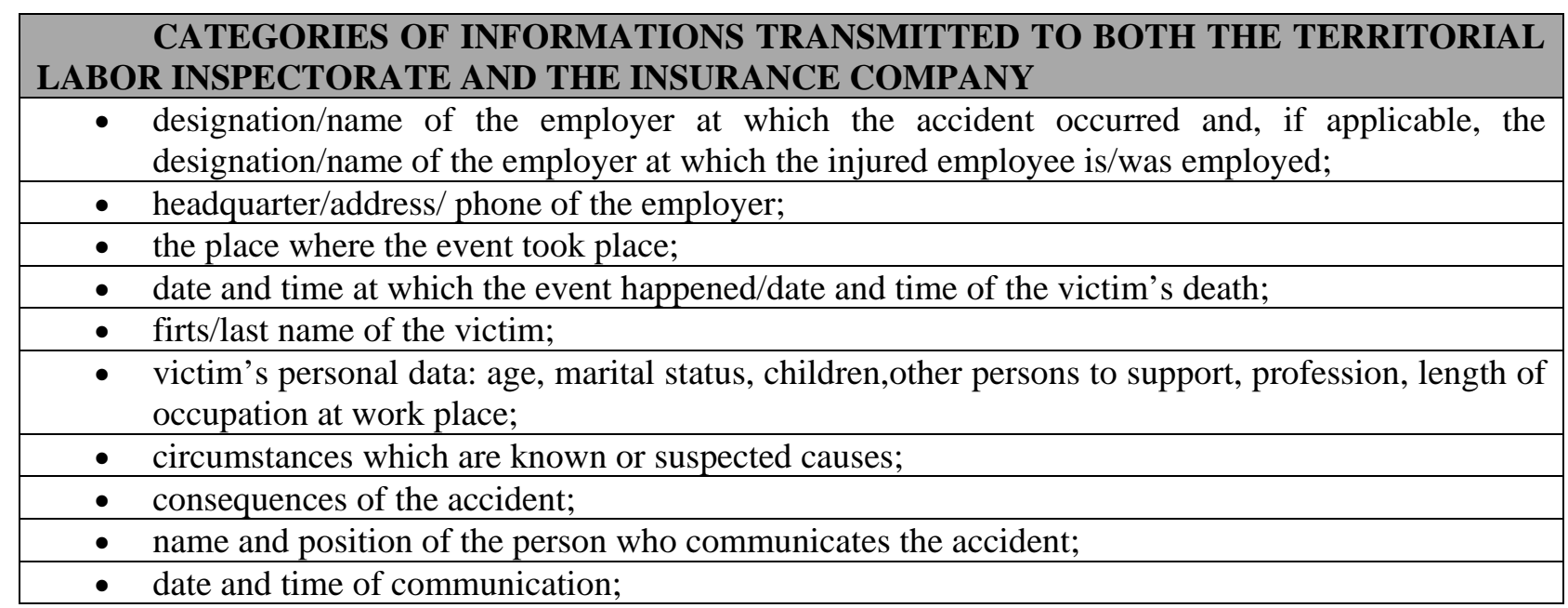

\section{The way in which communication is made}

Any event ${ }^{8}$ will be communicated immediately to the employer, by the head of the place of work or any other person who has knowledge of its production.

Legal rules stipulate that any event, as defined in the article 5 letter f), will be communicated immediately to the employer, by the head of the place of work or any other person who has knowledge about its production, and the employer has the obligation to communicate the events as soon as:

- to all teritorial labor insectorate;

- to the insurance company, according to the Law no. 346/2002 regarding the accidents at work and occupational diseases, with subsequent amendments and completions, events followed by temporary incapacity, invalidity or death in their confirmation;

-to the criminal prosecution, where applicable.

In the case of traffic accidents on public roads, which among the victims there are the persons performing the job duties, the competent bodies of the traffic police must send the employer and labor inspectorate within which the event occurred, within 5 days from the date of the request, a copy of the research report on the spot or any other documents required in conducting research.

\section{Competence of the investigation of work accidents}

The investigation of the events is obligatory and it is made immediately after communication according to the law provisions, article 29, paragraph 1 from Law no. 319/2006.

\begin{tabular}{|c|c|c|}
\hline & SITUATIONS & COMPETENCE OF INVESTIGATION \\
\hline work; & Events with temporary incapacity for & $\begin{array}{l}\text { Employer } \\
\text { Exception: } \\
\text { - cases in which the employees suffered } \\
\text { from an obvious invalidity; } \\
\text { - cases in which victims are foreigner } \\
\text { citizens; } \\
\text { - cases in which among victims there are } \\
\text { foreigner citizens. }\end{array}$ \\
\hline & $\begin{array}{l}\text { Events that generated invalidity } \\
\text { Death } \\
\text { Collective accidents } \\
\text { Dangerous incidents } \\
\text { Missing persons situations }\end{array}$ & Territorial Labor Inspectorates \\
\hline
\end{tabular}

\footnotetext{
${ }^{8}$ The event is the accident that has entailed the death or injury of the body during the process of carrying out their duties of employment or service situation of missing persons or route accident or in conditions in which they were involved employees, the dangerous incident and unlikely event of occupational disease or a related profession.
} 
Legal rules also determine that the occupational physician with whom the employer has contracted to provide services or any other doctor is obliged to notify the authority of the territorial public health, occupational diseases, as well as the suspicion of occupational disease, including acute occupational poisoning, traced to any medical benefits.

\section{Case study - death by work accident as a consequence of a route accident Short description of the accident}

On the 12th of October 2011, around 11:20, on the National Road 1, at $328 \mathrm{~km}$, outside Săliște, Sibiu County, there was a road traffic accident in the following circumstances:

The person, F.O., age of 56 years, holder of category B driving licence since 1993, while he was driving the Audi car on the route from Sibiu to Alba Iulia, was engaged in a overtaking movement of another vehicle, while from the opposite direction there was moving a Dacia Logan car that belonged to a public institution and driven by the person, G.L., a civil servant with special status who was during the execution of the service.

To avoid frontal crash, the driver of the Dacia Logan car pressed the brakes and suddenly changed the movement direction towards the right. At that moment, it entered the side collision with a Mercedes tractor that was moving on the same direction, on the first route drive lane. After the side crash with the Mercedes tractor, the Dacia Logan car was pushed on the opposite drive lane, when and where it got into frontal violent collision with the Audi car.

The accident resulted in both the driver's death of the Dacia Logan car, who was a civil servant with special status during the execution of his job, as well as serious injuries of two persons, respectively the driver and a passenger of the Audi car.

The way that the event was held was straight, flat, with an overall width of $10.5 \mathrm{~m}$ and bounded by the verge on $1 \mathrm{~m}$ on both sides. The traffic runs on three traffic lanes, two on each side on the direction from Sibiu to Alba Iulia and vice versa.

The analyses of the biological samples have proven the fact that the drivers involved were not under the influence of alcoholic beverages.

\begin{tabular}{|rl|}
\hline \multicolumn{1}{|l|}{ THE INVESTIGATION FILE OF THE CAR CRASH AS WORK ACCIDDENT } \\
\hline$>$ & the report of the investigation on the spot; \\
\hline$>$ & the photos taken; \\
\hline$>$ & the reports of medical confirmation of the victim's death; \\
\hline$>$ & the statements of the drivers who were witnesses; \\
\hline$>$ & sketch orientation of the crime scene; \\
\hline$>$ & notes and reports made by authorities in charge with the investigation. \\
\hline
\end{tabular}
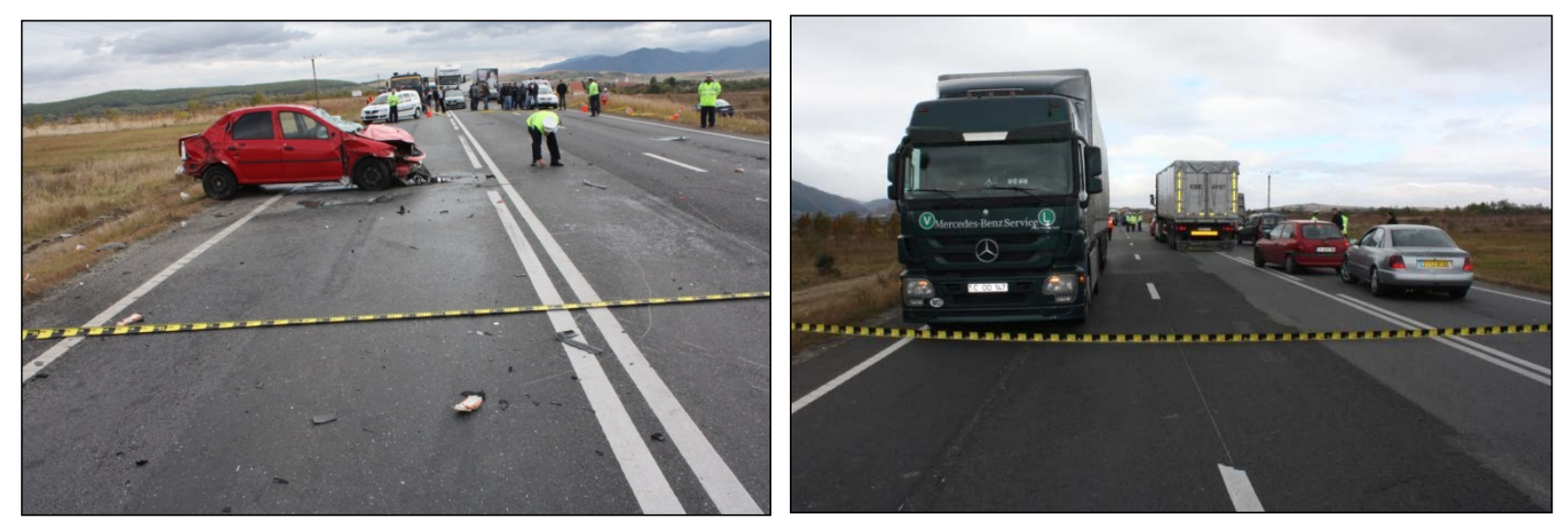

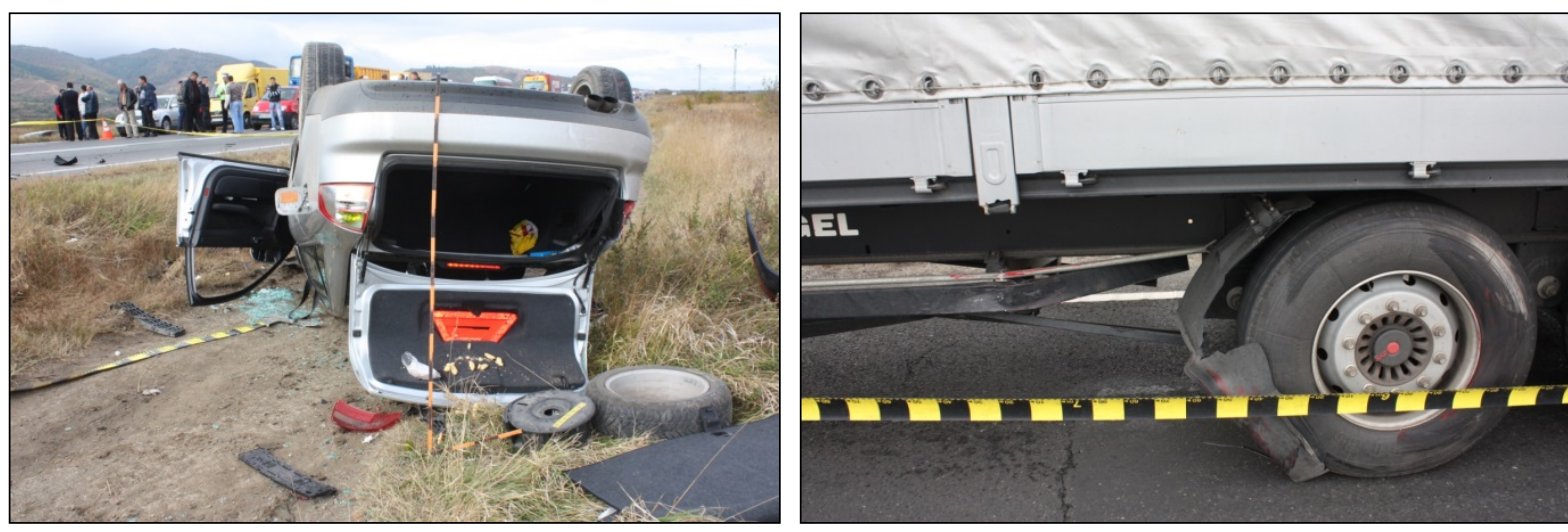

\section{Conclusions}

In terms of accident investigation, the investigation was carried out on the spot by a team of complex investigation consisting of several police officers and crime specialists and led by a prosecutor criminologist, and, in this case, it was drawn up a file of criminal investigation for the commitment of a murder of contributory negligence and grievous bodily harm.

In accordance with the provisions of the article 5, letter g) of the Law no. 319/2006 concerning safety and health in the workplace and of the article 2, point 9 of the Government Decision no. 1425/2006 approving the methodological rules for the application of provisions of the law on safety and health in work no. 319/2006, with subsequent amendments and additions, the event's investigation has revealed that the event constitutes a traffic accident.

In this particular case, the Commission of Investigation of the event did not have and formulate proposals with regard to the prosecution in respect of offences envisaged by Law no. 319/2006 concerning safety and health at work. In annex I, point 4 letter e) in the Government Decision no. 355/2007 concerning the supervision of the employees' health, supplemented and amended by Government Decision no. 1.169/2011 stated that:"from engaging in work, as well as on the occasion of periodic medical examination of employees who compete at traffic safety in railway transport, aviation, naval and of drivers sector, as well as other categories of employees carrying out specific activities, and examinations shall be carried out by special regulations, in order to go if the health conditions allow them to achieve what they are given work;"

In accordance with the article 136, paragraph 10 in Government Decision no. 1425/2006 approving the methodological rules for the application of provisions of the law on safety and health at work no. 319/2006, with subsequent amendments and completions, work accident shall be recorded at the official public employer with special status.

\section{References}

- Tudose, E., Sava,I., Georgescu, D., Corha, Y., Bolohan, A., Ganea, C.( 2013), Law on health and safety at work - Easy Implementation of Law with Models for the Management of Safety at Work, Forum Publishing House, Bucharest.

- Tarnu, L. I, Analysis, Investigation and Rebuilding of the Traffic Accidents, Universul Juridic Publishing House, Bucharest, 2012;

- Cioca, L. I., The Management of The Security and Health at Work,"Lucian Blaga”University in Sibiu Publishing House, Sibiu, 2009;

- The Law of security and health at work no. 319/2006;

- Government Decision no. 1425/2006 approving the methodological rules for the application of provisions of the law on safety and health at work no. 319/2006, with subsequent amendments and completions;

- Government Decision no. 355/2007 regarding the surveillence of the health of employees completed and amended by the Government Decision no. 1.169/2011;

- Law no. 346/2002 with the changes and amendments regarding on insurance for accidents at work and occupational diseases. 